\title{
Performance of Cooled Cone Grinding Machine in Cocoa Cake Processing
}

\author{
Hendy Firmanto ${ }^{1 *}$, Edy Suharyanto ${ }^{1)}$, and Kuswanto ${ }^{1)}$ \\ ${ }^{1}$ Indonesian Coffee and Cocoa Research Institute, Jl. PB. Sudirman 90, Jember Indonesia \\ ${ }^{*}$ Corresponding author: hendysan@yahoo.com
}

\begin{abstract}
The process of cocoa paste pressing has a function to separate the fatty components of cocoa from its cake. Cocoa paste is further processed into cocoa powder using grinding machine for cocoa cake. The cooled cone type of cocoa grinding machine is used to solve the problem of plug in the machine caused by melting of fat in cocoa cake due to hot effect as a result of friction in the grinding machine. Grinding machine of cocoa has conical form of cylinder for grinding and stator wall wrapped by source of cold and closed with jacket wool. Research was conducted at Kaliwining Experimental Station of Indonesian Coffee and Cocoa Research Institute using cocoa cake containing $26.8 \%$ cocoa fat originated from Forastero type of cocoa seed. The capacity and recovery of the machine was influenced by space between rotor cylinder and stator wall. Grinding machine operated at cooling temperature of $25.5^{\circ} \mathrm{C}$ and space between rotor-stator $0.9 \mathrm{~cm}$ and the capacity of $187.5 \mathrm{~kg} /$ hour with recovery of 200 mesh cocoa powder as much as $24 \%$. The maximum power of machine required was $2.5 \mathrm{~kW}$ with efficiency of energy transfer of $97 \%$. Results of proximate analysis showed that there was no change of protein content, however, protein and carbohydrate content increased after processing, i.e. from $5.70 \%$ and $59.82 \%$ into $5.80 \%$ and $61.89 \%$ respectively.
\end{abstract}

Keywords: cocoa cake, cooling, grinding, cocoa powder

\section{INTRODUCTION}

Cocoa powder is used as additional material or as flavor and aroma of food. Cocoa powder can also be used as natural colouring matter and as food layering substance such as in bisquit and ice cream (Kox, 2000). Cocoa powder is obtained from grinding and sieving of cocoa cake, which is the product of pressing process of cocoa paste to separate from fat component. Particle size of cocoa powder accepted for food material according to SNI 01-3747-1995 is about 200 mesh. Cocoa powder has variation of fat content in accordance with condition of operation during pressing. Cocoa cake with high fat content tends to melt if it is ground at the temperature of $27-30^{\circ} \mathrm{C}$ (Mulato \& Suharyanto, 2012). The roll type of grinding machine according to Sri-Mulato et al. (2010) has not yet produced 200 mesh powder size if it is only ground once during processing. The fat of cocoa consisted of stearic acid $(33.2 \%)$, oleic acid $(32.6 \%)$, myristic acid $(0.1 \%)$, and linolenic acid $(0.1 \%)$ (Endarti, 2007). Theobromine content of cocoa powder can reach $12.22 \mathrm{mg}$ (Maleyki et al., 2008).

Grinding machines normally used in the industry consisted of three types i.e. primary grinder, secondary grinder, and tertiary 
grinder each of which refers to range of particle size to be produced. The smallest size of powder is produced in the tertiary grinder step which can reach 100 mesh to 1250 mesh (Beckett, 2008). Temperature increase during process of grinding may influence physical and chemical properties of material to be ground. Heat can be produced by friction in the machine or friction between materials, therefore to prevent heating coolant can be used. The purpose of this experiment is to evaluate the performance of cooled grinding machine for cocoa cake with high fat content, and to determine physical quality or fineness of powder and chemical quality of cocoa powder using proximate analysis.

\section{MATERIALS AND METHODS}

Experiment was conducted at Departmen of Postharvest Processing of Indonesian Coffee and Cocoa Research Institute (ICCRI). Experiment was divided into three steps, i.e. designing grinding part, grinding machine for cocoa cake, testing the performance of the machine, and evaluation of the quality of cocoa powder produced consisting of recovery, fineness and nutritional content. Material of experiment was cocoa cake containing $26.8 \%$ fat, product of cocoa paste pressing. The cocoa cake was originated from Forastero cocoa seed with moisture content of $7.05 \%$ obtained from Kaliwining Experimental Garden of ICCRI. Instruments for testing were data acquisition Fluke, $\mathrm{Ni}$-CrNi sensor, and computer for allocation of temperature data, tachometer, and oven.

The conical cooled grinding machine for cocoa cake had four main parts, i.e. feeding part, grinding part, moving power, and cooling unit (Figure 1). Feeding part consisted of flat spoon plate made of aluminium with diameter of $40 \mathrm{~cm}$ supplied with slider. Grinding part consisted of spoon cone with diameter of $20 \mathrm{~cm}$ and height of $40 \mathrm{~cm}$, and had vertical destroyer spoon with $2 \mathrm{~cm}$ thickness and its distance could be changed by means of delicate wall (clearance). Moving power consisted of single phase electrical motor with voltage of $220 \mathrm{~V}$ and rotation power of $1400 \mathrm{rpm}$ that moved rotation axis cushion. The transmission of power from source of moving power to grinding cylinder used pulley system and rubber belt single $\mathrm{V}$, reduction of rotation using gear box with rotation ratio of 1:50 and size of 60. Proportion of gear wheel from gear box to rotation axle cushion was 1:1. Cooling unit or coolant used wrapping system consisted of condensor, compressor, and freon. Coolant wrapped on grinding part was also wrapped by woolen jacket for reducing heat transfer from environment to the machine. Temperature scale of cooling source was regulated with lowest temperature of $10^{\circ} \mathrm{C}$ under condition of production space temperature of $29^{\circ} \mathrm{C}$.

\section{Performance and product quality}

Performance of grinding machine for cocoa cake was evaluated at distance of clearance as much as $0.6 \mathrm{~cm}, 0.9 \mathrm{~cm}$, and $1.2 \mathrm{~cm}$ and cooling temperature of $26^{\circ} \mathrm{C}$, $25.5^{\circ} \mathrm{C}$ and $25^{\circ} \mathrm{C}$ respectively. Working capacity of machine $(\mathrm{Cm})$ was calculated according to equation:

$$
\mathrm{Cm}, \mathrm{kg} / \text { hour }=\frac{\text { Feeding material, } \mathrm{kg}}{\text { Grinding time, hour }}
$$

Power needed was calculated based on equation:

$$
\text { P. Watt }=I x \text { V }
$$

Notes:

$\mathrm{I} \quad=$ current measured during machine operation (ampere)

$\mathrm{V} \quad=\operatorname{voltage}($ volt $)$

Efficiency of power transmission ( $\eta \mathrm{d}$ ) was calculated using equation: 

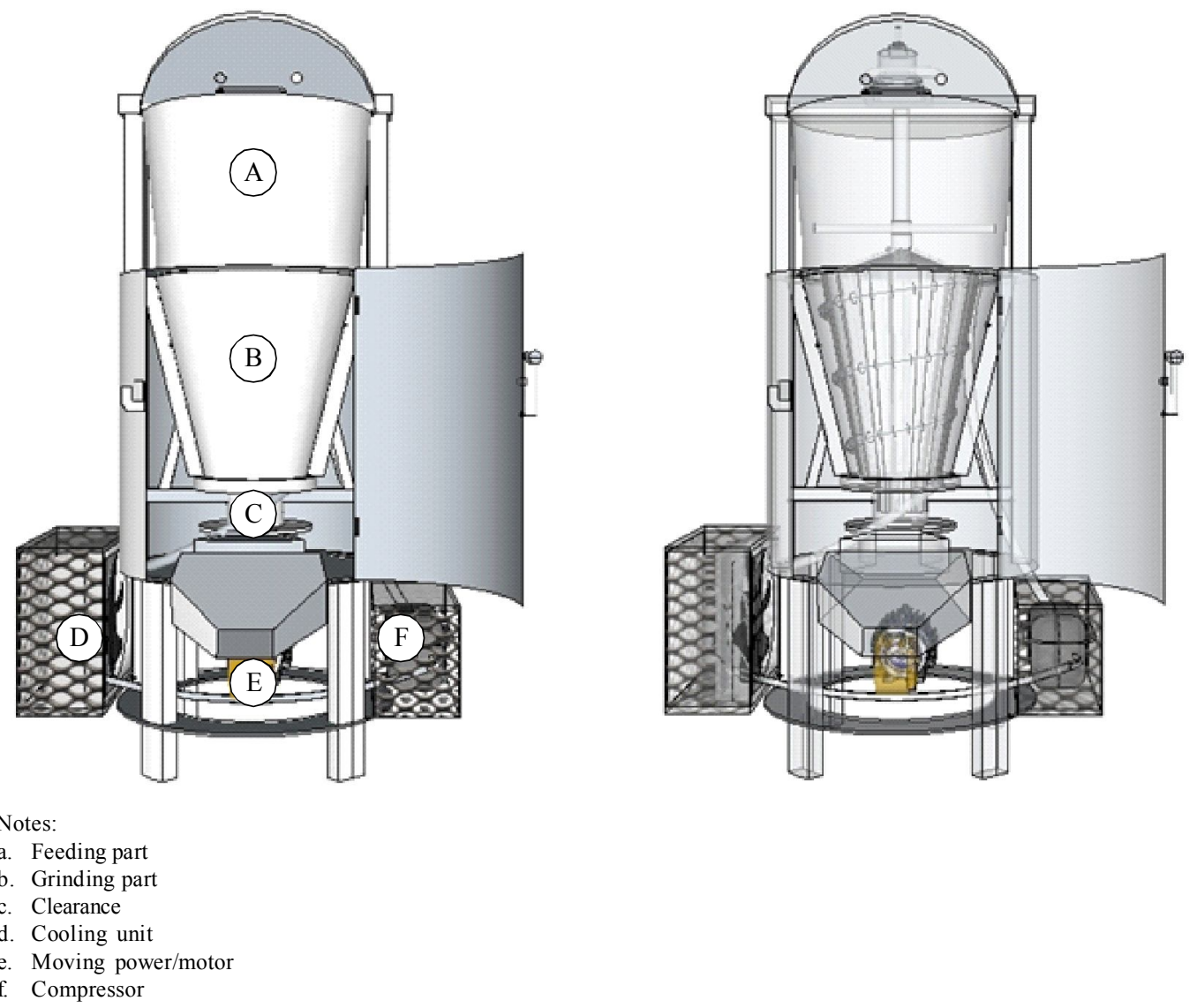

Figure 1. Design of cooled cone grinding machine

$\eta \mathrm{d}) . \%(\%)=\frac{\mathrm{n}_{2} \times \mathrm{d}_{2}}{\mathrm{n}_{1} \times \mathrm{d}_{1}} \times 100 \%$

Notes:

$\mathrm{n}_{1}=$ rotation of cylinder axle of moving motor $(\mathrm{rpm})$
$\mathrm{n}_{2}=$ rotation of main cylinder axle of grinding pulley $(\mathrm{m})$
$\mathrm{d}_{1}=$ diameter of grinding pulley $(\mathrm{m})$

The powder produced by grinding was sieved using 25 mesh, 100 mesh, and 200 mesh sized sieve and the recovery was calculated. Cocoa powder was analyzed with proximate analysis, by testing carbohydrate content using Luff Schoorl method, testing protein content by means of micro Kjeldahl, and testing fat content using Soxhlet method.

\section{RESULTS AND DISCUSSION}

Cocoa cake could have fat content between $10 \%$ and $22 \%$ depending on condition of pressing its paste. The high fat content in cocoa cake became a problem in the process of grinding because it would produce heat due to friction between rotor and stator, or between grinder and the material ground. The excessive heat caused heating of the cocoa cake up to its melting point at $27-30^{\circ} \mathrm{C}$. The melting cocoa cake during grinding would plug the machine and increased the occurrence of oxydation of fatty component inside and therefore increased the potential 
of rancidity (Morris, 1954). The excessive heat in the machine could be reduced by installing cooling apparatus to prevent change of quality of the material processed (Meursing \& Zijderveld, 1999). The installation of cooling source in ground space wouldlike to absorve heat so that the material of cocoa cake with high fat content did not melt (Rowe \& Jin, 2001).

\section{Grinding process temperature}

Low temperature in the grinding space of cocoa cake was produced by Freon system wrapped and isolated the whole surface of grinding space. Temperature of cooling source $\left(\mathrm{T}_{0}\right)$ was arranged at $26^{\circ} \mathrm{C}$, $25.5^{\circ} \mathrm{C}$, and $25^{\circ} \mathrm{C}$, and distance between grinding cylinder and wall (S) or clearance was settled at $0.6 \mathrm{~cm}, 0.9 \mathrm{~cm}$ and $1.2 \mathrm{~cm}$. Results of evaluation of machine temperature in grinding $25 \mathrm{~kg}$ cocoa cake with arrangement of cooling temperature $\left(\mathrm{T}_{0}\right)$ and distance between rotor and stator (S) showed different temperature fluctuation as illustrated in Figure 2, i.e. at $\mathrm{T}_{0} 26^{\circ} \mathrm{C}, 25.5^{\circ} \mathrm{C}$, and $25^{\circ} \mathrm{C}$, each of which reached temperature range of $23-19^{\circ} \mathrm{C}, 21-10^{\circ} \mathrm{C}$, and $18-6^{\circ} \mathrm{C}$. The narrow distance between rotor-stator (S) increased the temperature (Figure 2a) with smallest $\mathrm{S}$ tended to be in the upper side (Figure 2c). Difference temperature between grinding space $\left(\mathrm{T}_{\mathrm{i}}\right)$ and cooling temperature $\left(\mathrm{T}_{0}\right)$ was not always the same, in which at $\mathrm{T}_{0}=26^{\circ} \mathrm{C}$ could differ about $6^{\circ} \mathrm{C}$, while at $\mathrm{T}_{0}=25.5^{\circ} \mathrm{C}$ the difference was about $11^{\circ} \mathrm{C}$. This showed that cooling temperature $\left(\mathrm{T}_{\mathrm{i}}\right)$ beside influenced by clearance it was also influenced by environmental condition (Geankoplis, 1983) like change of specific mass of water vapour by change of air density and space temperature. Grinding machine operated at space temperature of $29^{\circ} \mathrm{C}$ and $75 \%$ humidity according to Smith \& Van Ness (1987) would expose water vapour around at dew point temperature $\left(24^{\circ} \mathrm{C}\right)$, so that temperature of cooling source was arranged minimum at $25^{\circ} \mathrm{C}$ to prevent the grinding machine exposed to excess of water originated from water vapour in the air. The results showed that grinding machine could be operated at temperature of cooling source at $25-26^{\circ} \mathrm{C}$ without plug although dew existed in grinding space. Water vapour from the environmental air was still relative low to be able to wet cocoa cake and therefore it did not disturb performance of the machine.

\section{Working capacity}

Grinding machine of cocoa cake had been developed beforehand by Widyotomo \& Sri-Mulato (2004) without using cooling system, the capacity of which was 5 to $10 \mathrm{~kg}$ for one time grinding that required 30 minutes processing time. Working capacity of grinding machine for cocoa cake with fat content of $26.75 \%$ at different cooling temperature $\left(\mathrm{T}_{0}\right)$ and clearance $(\mathrm{S})$ was presented in Figure 3. The highest temperature $T_{0}$ at $25.5^{\circ} \mathrm{C}$ did not much influence to the capacity of the grinding machine, but at temperature above $25.5^{\circ} \mathrm{C}$ the capacity of machine tended to decrease in accordance with decrease of clearance distance. Machine capacity at clearance (S) $0.9 \mathrm{~cm}$ and $1.2 \mathrm{~cm}$ was a little bit higher than clearance $=0.6 \mathrm{~cm}$ for temperature condition. Average capacity of grinding machine was $185 \mathrm{~kg}$ /hour, and optimum capacity was observed at cooling temperature of $25.5^{\circ} \mathrm{C}$ with clearance of $0.9 \mathrm{~cm}$ and $1.2 \mathrm{~cm}$, i.e. $187.5 \mathrm{~kg} /$ hour, whereas capacity at $26^{\circ} \mathrm{C}$ with clearance of $0.9 \mathrm{~cm}$ and $1.2 \mathrm{~cm}$ was $183.8 \mathrm{~kg} /$ hour.

\section{Power requirement and efficiency}

Cooling source in grinding machine would hand to hand with source of power when being operated, and therefore power requirement was influenced by temperature of cooling source and distance (clearance) 

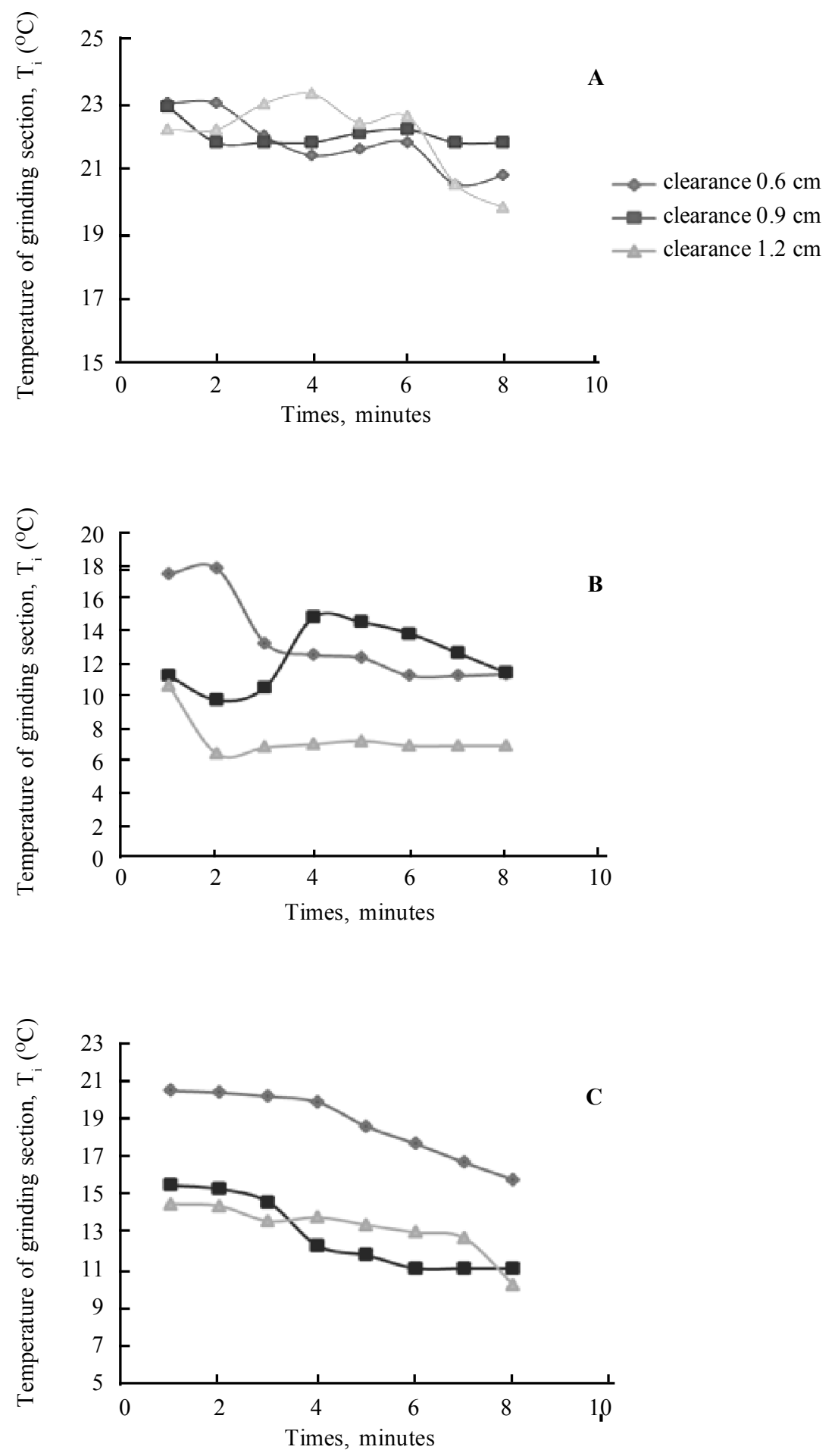

Figure 2. Temperature profile of grinding section by cooling temperature arranged at $26^{\circ} \mathrm{C}(\mathrm{A}), 25.5^{\circ} \mathrm{C}(\mathrm{B})$ and $25^{\circ} \mathrm{C}(\mathrm{C})$ 


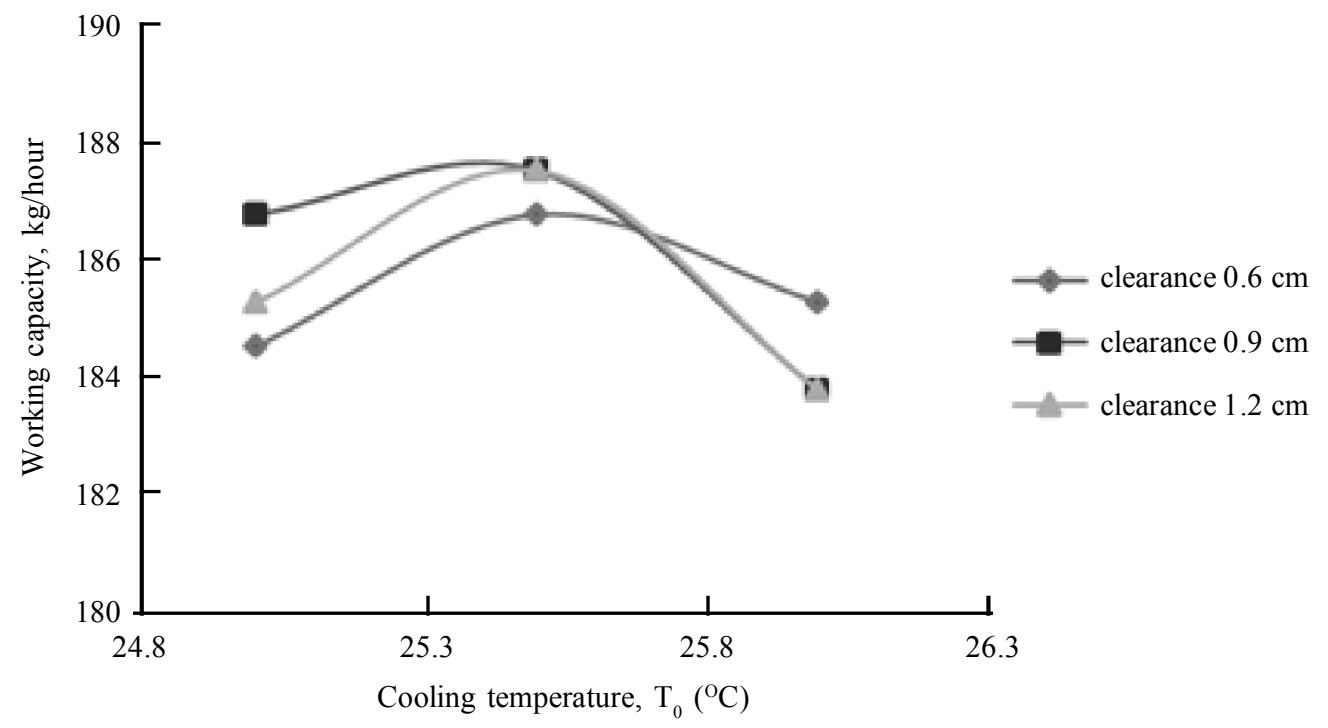

Figure 3. Working capacity of cocoa cake grinding machine

used. Figure 4 showed that in the same loading capacity the power required was proportional to increase of temperature and clearance. The higher the temperature of cooling unit used to cool grinding space the smaller was the power needed, and the higher the clearance used the lower also the power needed. Each $1{ }^{\circ} \mathrm{C}$ temperature increase of cooling source decreased the power needed by $1.25 \mathrm{~kW}$ for clearane of $1.2 \mathrm{~cm}, 0.78 \mathrm{~kW}$ for clearance of $0.9 \mathrm{~kW}$ and $0.52 \mathrm{~kW}$ for clearance of $0.6 \mathrm{~cm}$. The highest power needed for grinding was $2.5 \mathrm{~kW}$.

Table 1 showed linear regression equation and correlation coefficient $\left(\mathrm{R}^{2}\right)$ between temperature of cooling source and capacity of machine produced. Linear regression equation was used to predict the power requirement of cocoa cake grinding machine if the temperature of cooling source was $25-26^{\circ} \mathrm{C}$ and clearance distance was $0.6 \mathrm{~cm}$ to $1.2 \mathrm{~cm}$. Power requirement in grinding process followed linear regression equation $\mathrm{Y}=-280.5 \mathrm{X}+1984$ with corellation coefficient
$=1 . \mathrm{X}$ was temperature of cooling source $\left({ }^{\circ} \mathrm{C}\right)$ and $\mathrm{Y}$ was power requirement (Watt) of the grinding machine.

The efficiency of cocoa cake grinding machine was evaluated by means of power transmission efficiency. By adding cooling unit efficiency of power transmission of the machine at different condition of grinding was more than $95 \%$. Value of power transmission efficiency was presented in Figure 5 which showed effect of temperature of cooling source on value of power transmission efficiency. The lower temperature of cooling source was proportional with level of power transmission efficiency, so that the lowest temperature woul dlike to produce optimum efficiency. At cooling source temperature of $25^{\circ} \mathrm{C}$ the efficiency was better than at temperature of $26^{\circ} \mathrm{C}$. Clearance distance of $0.6 \mathrm{~cm}$ with efficiency value of $97.8 \%$ was the efficient distance for grinding cocoa cake and did not produce broken cocoa that was difficult to grind or left in the machine. 


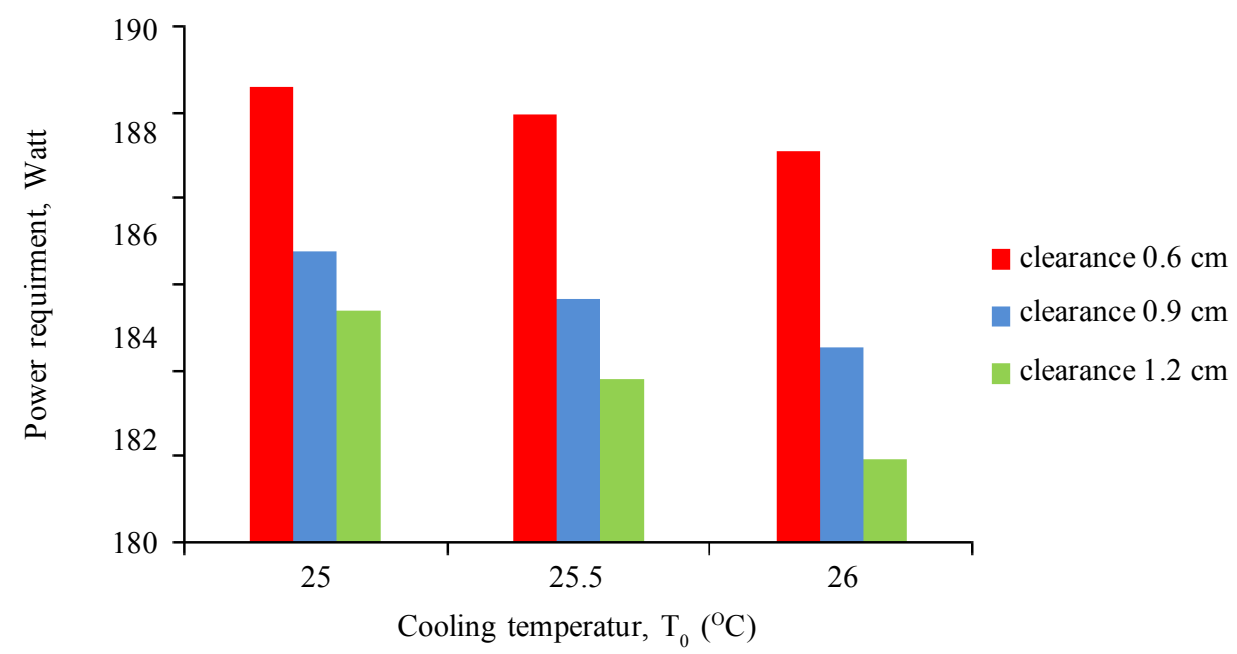

Figure 4. Power requirement of cocoa cake grinding machine

Cocoa powder accepted in the market generally had specification of particle size that was able to penetrate 200 mesh sieve following SNI 3747-2009 standard. Recovery of cocoa powder produced by grinding machine was sieved using 25 mesh, 100 mesh, and 200 mesh size of sieve to determine if the machine was of the first fine type ( $<100$ mesh). Figure 6 showed effect of cooling source temperature and clearance on recovery of 200 mesh powder with highest recovery as much as $24 \%$ obtained at temperature of cooling unit $\left(\mathrm{T}_{0}\right)$ of $25.5^{\circ} \mathrm{C}$ and optimum distance of $0.9 \mathrm{~cm}$. Recovery of cocoa powder with the size of 25 mesh or smaller had higher percentage so that this grinding machine was more appropriate to be used as early grinding machine, and should be followed by further process of grinding in order to get higher recovery for 200 mesh powder size.
Product quality of cocoa powder was also determined by nutrition content that revealed from proximate analysis on content of carbohydrate, protein, fat, moisture, and ash for determining its change during processing. Results of quality evaluation was presented in Table 2 where decrease of moisture content was also followed by increase of carbohydrate and fat content. Protein content of the product remained the same at different moisture content, possibly due to denaturation of the protein. According to Lehninger (1998) denaturation of protein could happen in processing at moderate temperature $\left(60-90^{\circ} \mathrm{C}\right)$ during about one hour, however temperature of grinding process did not reach that temperature so that damage of protein might be due to mechanical treatment such as grinding. Mechanical treatment might cause stretching of protein chain structure to that protein was liable to damage (Muchtadi, 1989). 
Table 1. Equation requirement of cocoa cake grinding machine

\begin{tabular}{lcc}
\hline Clearance & Liniear regression equation & Correlation coefficient, $r$ \\
\hline 0.6 & $\mathrm{Y}=-183.7 \mathrm{X}+2843$ & 0.993 \\
0.9 & $\mathrm{Y}=-280.5 \mathrm{X}+1984$ & 1.000 \\
1.2 & $\mathrm{Y}=-431.2 \mathrm{X}+1797$ & 0.998 \\
\hline
\end{tabular}

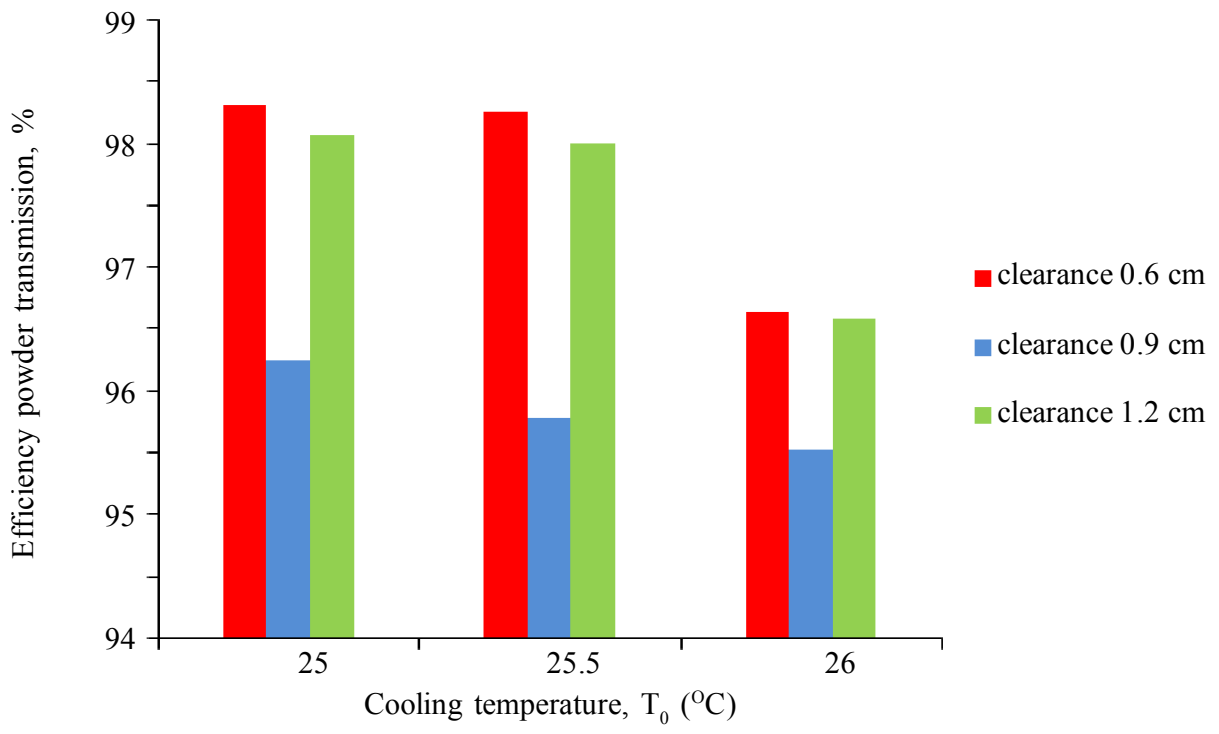

Figure 5. Powder transmission efficiency of cocoa cake grinding machine 

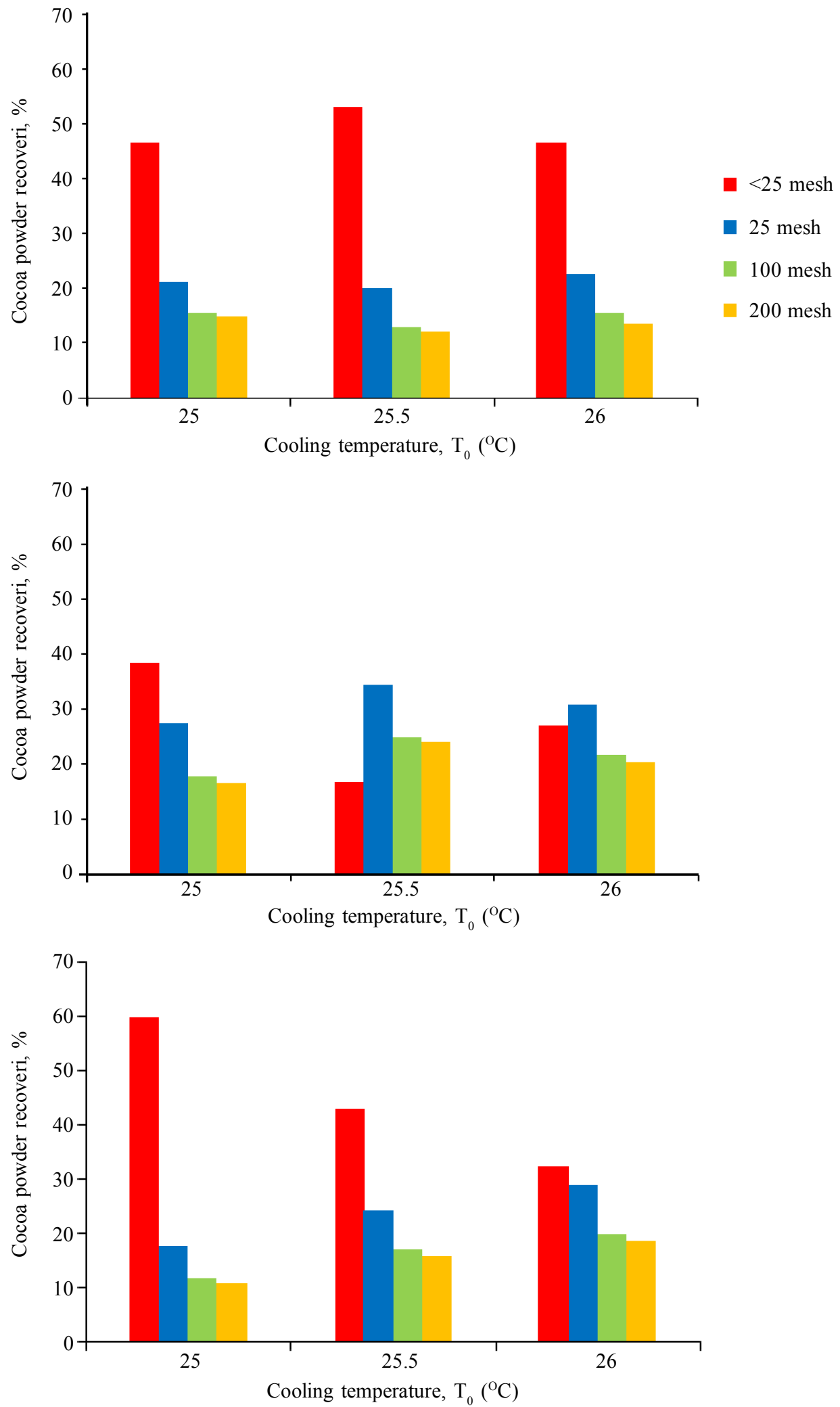

Figure 6. Cocoa powder recovery on clearance 1,2 $\mathrm{cm}(\mathrm{A}) ; 0,9 \mathrm{~cm}(\mathrm{~B})$; and 0,6 $\mathrm{cm}(\mathrm{C})$ as affected by cooling temperature 
Tabel 2. Result of proximate analysis of cake and cocoa powder

\begin{tabular}{lcc}
\hline Component & Cocoa cake, \% & Cocoa powder, \% \\
\hline Carbohydrate & 59.82 & 61.89 \\
Fat & 5.70 & 5.80 \\
Protein & 22.59 & 22.59 \\
Ash & 4.15 & 4.29 \\
Water & 5.13 & 5.03 \\
\hline
\end{tabular}

\section{CONCLUSION}

1. Grinding machine of cocoa cake could be well operated by installing unit of cooling source in grinding space at the temperature of $25-26^{\circ} \mathrm{C}$ with optimum capacity of $187.5 \mathrm{~kg} / \mathrm{hour}$, in which melting process of the cake during processing was prevented.

2. Power requirement at optimum condition was $2.5 \mathrm{~kW}$ per batch whereas efficiency of power transmission was $97.8 \%$.

3. Recovery of cocoa powder with optimum particle size of 200 mesh was only $24 \%$, while the majority of particle size was $<25$ mesh, so that this machine was included in primary grinder, and therefore further grinding was needed.

4. The process of grinding had only small influence on decrease of protein content in cocoa powder produced.

\section{ACKNOWLEDGEMENT}

The author would like to thank Dr. Sri-Mulato for his suggestion during the beginning of this work, to Prof. Tarzan Sembiring for his comments on the manuscript, and to Husnul Chotimah (Physical Technique Department, ITS) for her evaluation on the machine draft. This research was funded by ICCRI's routine research fund.

\section{REFFERENCES}

Beckett, S.T. (2008). The Science of Chocolate. The Royal Society of Chemistry. Thomas Graham House: Cambridge UK.

Endarti, E. (2007). Optimasi perolehan Lemak Kakao secara Pengepresan dengan Variasi Tekanan dan Waktu. Tesis. Fakultas Teknologi Pertanian Institut Pertanian Bogor, Bogor.

Geankoplis, C.J. (1983). Transport Process and Unit Operation, $2^{\text {nd }}$ ed. Allyn and Bacon Inc. Boston, USA.

Kox, H.L.M. (2000). The Market for Cocoa Powder. Economic and Social Institute Free University, Amsterdam.

Lehninger, A.L. (1998). Dasar-Dasar Biokimia. Terjemahan, M. Thenawidjaja. Pustaka Sinar Harapan, Jakarta.

Maleyki; M.J. Abbe \& A. Ismail (2010). Antioxidant properties of cocoa powder. Journal of Food Biochemistry, 34, 111-128.

Meursing, E.H. \& J.A. Zijderveld (1999). Cocoa Mass, Cocoa Butter and Cocoa Powder in Industrial Chocolate Manufacture and Use, $3^{\text {rd }} e d$. Blackwell: Oxford UK.

Morris, S.G. (1954). Fat rancidity, recent studies on mechanism of fat oxidation in its relation to rancidity. Journal of Agriculture and Food Chemistry, 2, 126-132.

Muchtadi, T.R. (1989). Teknologi Proses Pengolahan Pangan. Departemen Pendidikan dan Kebudayaan, Direktorat Jenderal Pendidikan Tinggi, Pusat Antar Universitas Pangan dan Gizi, Institut Pertanian Bogor. 
Rowe, W.B. \& T. Jin (2001). Temperatures in high efficiency deep grinding (HEDG). CIRP Annalis Manufacturing Technology, 50, 205-208.

Sri-Mulato \& E. Suharyanto (2012). Kawasan Tekno Agro, Pengembangan Produk Berbasis Kopi dan Kakao. Pusat Penelitian Kopi dan Kakao Indonesia, Jember.

Sri-Mulato; S. Widyotomo \& Handaka (2010). Desain teknologi pengolahan pasta, lemak dan bubuk cokelat untuk kelompok tani. Warta Penelitian dan Pengembangan Pertanian, 26, 1-3.
Smith, J.M. \& H.C. Van Ness (1987). Introduction to Chemical Engineering Thermodynamics, $4^{\text {th }}$, McGraw-Hill (Ed.).

Widyotomo, S. \& Sri-Mulato (2004). Kemajuan Perekayasaan alat dan mesin pengolahan produk hilir kakao skala menengah. Prosiding Seminar Nasional Mekanisasi Pertanian. Balai Besar Pengembangan Mekanisasi Pertanian, Bogor.

$$
* * 0 * *
$$

